\title{
Heterotrophic nanoflagellate grazing facilitates subarctic Atlantic bloom development
}

\author{
Paulsen, Maria Lund; Riisgaard, Karen; St. John, Michael; Thingstad, T. Frede; Nielsen, Torkel Gissel
}

Published in:

Aquatic Microbial Ecology

Link to article, DOI:

10.3354/ame01807

Publication date:

2017

Document Version

Publisher's PDF, also known as Version of record

Link back to DTU Orbit

Citation (APA):

Paulsen, M. L., Riisgaard, K., St. John, M., Thingstad, T. F., \& Nielsen, T. G. (2017). Heterotrophic nanoflagellate grazing facilitates subarctic Atlantic bloom development. Aquatic Microbial Ecology, 78, 161-176. https://doi.org/10.3354/ame01807

\section{General rights}

Copyright and moral rights for the publications made accessible in the public portal are retained by the authors and/or other copyright owners and it is a condition of accessing publications that users recognise and abide by the legal requirements associated with these rights.

- Users may download and print one copy of any publication from the public portal for the purpose of private study or research.

- You may not further distribute the material or use it for any profit-making activity or commercial gain

- You may freely distribute the URL identifying the publication in the public portal 


\title{
Heterotrophic nanoflagellate grazing facilitates subarctic Atlantic spring bloom development
}

\author{
Maria Lund Paulsen ${ }^{1,2, *}$, Karen Riisgaard ${ }^{1}$, Michael St. John ${ }^{1}$, T. Frede Thingstad ${ }^{2}$, \\ Torkel Gissel Nielsen ${ }^{1}$ \\ ${ }^{1}$ National Institute of Aquatic Resources, DTU-Aqua, Section for Ocean Ecology and Climate, \\ Technical University of Denmark, Jægersborg Allé 1, 2920 Charlottenlund, Denmark \\ ${ }^{2}$ Marine Microbiology Research Group, Department of Biology, University of Bergen, Thormøhlensgate 53 A/B, \\ 5020 Bergen, Norway
}

\begin{abstract}
The subarctic Atlantic phytoplankton spring bloom is one of the largest biological features of the ocean; however, processes initiating the bloom are still not well understood. We hypothesize that the microbial grazing food chain plays an important role in creating a pre-bloom condition with top-down control of small-sized phytoplankton, thus paving the way for a diatomdominated spring bloom. To assess the trophic role of protist grazers during the winter to spring transition, 3 experiments were performed using size-fractionated surface water from the Iceland Basin (March-April 2012). These experiments demonstrated heterotrophic nanoflagellates (HNF) grazing of picophytoplankton to be a key pathway, even though these are rarely considered as important phytoplankton grazers in high-latitude systems. The growth rate of HNF was significantly correlated to the biomass of picophytoplankton and was substantially higher than the growth of the larger microzooplankton (MZP), i.e. ciliates and dinoflagellates. During the first experiment, small phytoplankton dominated and overall protist grazing (HNF + MZP) was low. In the later experiments, MZP grazing on HNF became evident; however, MZP were not able to control the community of larger phytoplankton $(>10 \mu \mathrm{m})$, which became more abundant. Our experiments thus support the hypothesis that pre-bloom conditions promote a build-up of large phytoplankton, i.e. diatoms. We found that the high growth rates of HNF together with the relaxed MZP grazing pressure allow HNF to respond rapidly to the early primary production by picophytoplankton and maintain a strong top-down control on these. We suggest that this succession may be an important mechanism that allows large diatoms, rather than picophytoplankton, to become the dominant primary producers during the subarctic Atlantic spring bloom.
\end{abstract}

KEY WORDS: Microbial food web · Fractionation experiment · Pre-bloom - Bloom development · Picophytoplankton · Heterotrophic nanoflagellates · Microzooplankton · Top-down control

\section{INTRODUCTION}

The North Atlantic spring bloom forms a direct link to higher trophic levels and is a major contributor to the global biological carbon pump (Boyd \& Newton 1995). It is one of the largest phytoplankton blooms in the ocean and has fascinated biological oceanographers for decades (e.g. Sverdrup
1953, Cushing 1959, Siegel et al. 2002, Taylor \& Ferrari 2011). The bloom is recognized as a seasonal feature, and the timing of the bloom, which is critical for the development of zooplankton, can vary between years and between regions (Friedland et al. 2016). In the present study, the spring bloom initiated in early May (Daniels et al. 2015). 
The first hypothesis to explain the onset of the spring bloom was based on observations from Weather Station Mike in the subarctic Atlantic $\left(66^{\circ} \mathrm{N}, 2^{\circ} \mathrm{E}\right)$ by Sverdrup (1953). The critical depth hypothesis proposed that the blooms were initiated firstly due to the seasonal increase in light and heat, releasing the community from light limitation, and secondly, due to increasing thermal stratification, allowing retention of phytoplankton in the euphotic zone. As a result, net growth rates exceeded net loss rates, leading to the build-up of biomass and the spring bloom. However, in the last 2 decades, the critical depth hypothesis has been challenged, as winter studies revealed that the North Atlantic spring bloom actually starts 1 to 2 months before the establishment of the stratification (Garside \& Garside 1993, Townsend et al. 1994, Dale 1999).

The survival of phytoplankton during winter is evidently critical for development during spring. Backhaus et al. (2003) and de Boyer Montégut et al. (2004) hypothesized that during winter, deep convection enabled primary production by periodically introducing phytoplankton to the photic zone during their circulation within the deep mixed layer, allowing growth that compensated for losses due to sinking. This hypothesis was challenged by Behrenfeld (2010), who explained the apparent net growth of phytoplankton during deep winter mixing by a reduced grazing pressure caused by the low encounter between phytoplankton and their grazers (the dilution recoupling hypothesis). Taylor \& Ferrari (2011) suggested that the net increase in phytoplankton biomass occurred as the convective movements lost momentum, before stratification was established (convective shut-down). During this period, net growth in the surface waters despite an apparent homogeneous water column is proposed due to so-called Huisman events (Huisman et al. 1999), where levels of turbulence are reduced and planktonic organisms are retained in the euphotic zone. The factors initiating and regulating the bloom are thus disputed and have been reviewed by Lindemann \& St. John (2014). They presented a conceptual model where a combined effect of low grazing pressure, low community respiration and periods of convective mixing compensated for cell sinking and the limited light exposure, leading to the net increase in phytoplankton biomass. However, they state that more knowledge about the growth and grazing potential of the plankton community is necessary to understand the mechanisms initiating and regulating the bloom development.

Phytoplankton are known to be top-down controlled by both microzooplankton (MZP) (e.g. Behrenfeld
2010) and mesozooplankton (e.g. Gislason et al. 2000). In the North Atlantic, the main mesozooplankton grazers (Calanus spp.) are in diapause deep below the mixed layer until spring, normally emerging during bloom maximum (Gislason et al. 2000). Thus it is the surface overwintering MZP that are the main phytoplankton grazers during pre-bloom along with small copepods, e.g. Oithona spp. (Nielsen \& Sabatini 1996). MZP are recognized as major regulators of phytoplankton during the bloom and postbloom conditions in the North Atlantic (Verity et al. 1993, Gifford et al. 1995). However, the impact of the smallest protist grazers, the heterotrophic nanoflagellates (HNF), on phytoplankton dynamics in high-latitude systems represents an information gap and is often ignored (e.g. Verity et al. 2002, Behrenfeld \& Boss 2014, Friedland et al. 2016). Overall, there is limited knowledge on both the MZP and HNF grazing community during winter and the winter-spring transition.

To assess the conditions contributing to the North Atlantic spring bloom, the EURO BASIN Deep Convection Cruise was undertaken from 26 March to 1 May 2012. Throughout this multidisciplinary cruise, 3 localities in the subarctic Atlantic were studied during the winter-spring transition to test the effects of deep convective mixing on, e.g., phytoplankton composition and primary production (Daniels et al. 2015), vertical distribution of autotrophic and heterotrophic microorganisms (Paulsen et al. 2015) and phytoplankton growth rates and herbivorous protist grazing rates (Morison \& Menden-Deuer 2015). Paulsen et al. (2015) documented a homogeneous distribution of the pico- and nano-sized microorganisms throughout the mixed layer and an increase in size and abundance of heterotrophic protists prior to the onset of the actual spring bloom. Small phytoplankton $(<10 \mu \mathrm{m})$ dominated in terms of abundance (Paulsen et al. 2015) and primary productivity (Daniels et al. 2015) during the pre-bloom, but with the relative importance of the very smallest phytoplankton, the picophytoplankton $(<2 \mu \mathrm{m})$, decreasing as diatoms became more abundant (Daniels et al. 2015). Interestingly, diatoms appeared to benefit from deep mixing, while small phytoplankton only remained dominant at the station in the Norwegian Basin where the water column was more stratified. MZP abundance decreased with increasing mixed layer depth, while HNF abundance remained unaffected by mixing. Paulsen et al. (2015) suggested that the relative decrease in picophytoplankton abundance could be caused by strong top-down control by a 
fast-growing community of $\mathrm{HNF}$, thereby proposing that fast-growing nano-sized grazers were able to compensate for the dilution and that grazing pressure was thus not reduced for all phytoplankton groups. This hypothesis also offers an explanation as to why the grazing experiments using the dilution technique (Landry \& Hassett 1982) performed during the cruise by Morison \& MendenDeuer (2015) did not show any association between the depth of the mixed layer (i.e. degree of dilution) and phytoplankton grazing. Clearly there is a need to understand the microbial interactions behind the chl a values, which are often used as a proxy in dilution experiments and studies based on remote sensing (e.g. Behrenfeld 2010), in more detail in order to understand the role of protist grazing.

Based on the findings of Paulsen et al. (2015) and Morison \& Menden-Deuer (2015), we hypothesize that during the winter-spring transition, HNF respond faster to the increase in primary production than MZP by having a higher net growth rate, and as a consequence: (1) HNF maintain a strong topdown control on picophytoplankton; (2) HNF become the main grazer during this period, as they are not top-down controlled by MZP; (3) larger phytoplankton, i.e. diatoms, benefit from the condition as they experience both low grazing pressure from MZP and mesozooplankton and in addition low nutrient competition from small phytoplankton, thus allowing bloom development.

We studied microbial interactions using sizefractionation incubation experiments, from which we can evaluate how the heterotrophic protist community influenced the succession of the phytoplankton community. Further, we include observations on bacteria, which are also grazed by heterotrophic protists, and abundance of viruses that are also known to be strong top-down regulators of both phytoplankton (Sandaa \& Larsen 2006) and bacteria (Fuhrman 1999), throughout the experiments.

\section{MATERIALS AND METHODS}

\section{Location and sampling}

The study was conducted aboard the RV 'Meteor', University of Hamburg, from 26 March to 1 May 2012 during the EURO BASIN Deep Con- vection Cruise (cruise no. 87) and based on experiments and observations from a time series station in the Iceland Basin $\left(61.5^{\circ} \mathrm{N}, 11^{\circ} \mathrm{W}\right)$, which was visited 3 times (Fig. 1). During each visit, vertical profiles of temperature, salinity and photosynthetically active radiation (PAR) were obtained using a Sea-Bird CTD (SBE 9 plus) with an attached rosette of $10 \mathrm{l}$ Niskin bottles. The depth of the mixed layer was defined by a decrease of $0.2^{\circ} \mathrm{C}$ from the surface $(10 \mathrm{~m})$ temperature (de Boyer Montégut et al. 2004). At each visit, 3 CTD profiles and discrete water samples were collected within a time frame of 20 to $36 \mathrm{~h}$ to capture temporal variation. Concentrations of $\mathrm{chl} a_{1}$ nitrate and nitrite $\left(\mathrm{NO}_{3}{ }^{-}+\mathrm{NO}_{2}^{-}\right)$, phosphate $\left(\mathrm{PO}_{4}{ }^{+}\right)$and silicic acid $\left(\mathrm{H}_{4} \mathrm{SiO}_{4}\right)$ (hereafter: $\mathrm{N}, \mathrm{P}$ and $\mathrm{Si}$ ), and abundances of microorganisms (bacteria, viruses, autotrophic and heterotrophic flagellates, as well as dinoflagellates and ciliates) were measured. Detailed methods are provided in Paulsen et al. (2015).
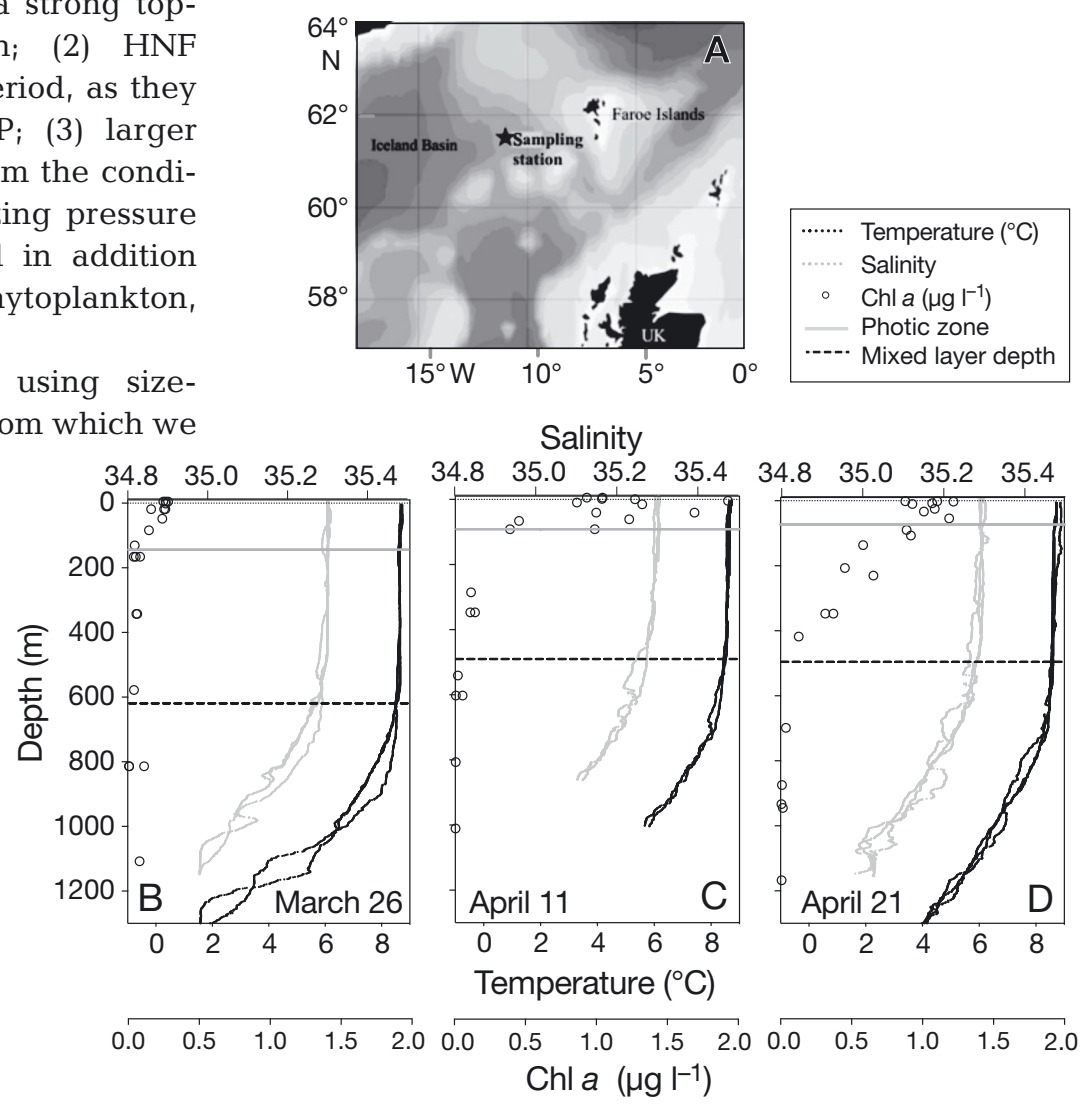

Fig. 1. (A) Sampling area ( $\star$ ) in subarctic Atlantic at the $1350 \mathrm{~m}$ deep sampling station in Iceland Basin $\left(61.5^{\circ} \mathrm{N}, 11^{\circ} \mathrm{W}\right)$. (B-D) Vertical profiles of temperature, salinity and total chl a from which water for Expts I, II and III were collected on 26 March, 11 April and 21 April 2012, respectively. Profiles were measured 3 times within $20-36$ h at each sampling occasion. Horizontal black dashed line: mixed layer depth; horizontal grey line: photic zone 


\section{Fractionation experiments}

Growth and grazing rates of the microbial components were estimated from 3 fractionation experiments: Expts I, II and III initiated on 26 March, 11 April and 21 April, respectively. For these experiments, water was collected from the photic zone at $30 \%$ surface light $(\sim 30 \mathrm{~m})$ and directly gently siphoned into dark carboys. Prior to the setup, bottles and carboys were acid-washed and then rinsed in Milli-Q water. A total of 501 was screened through one of 3 filters with different pore sizes: 50, 10 and $0.8 \mu \mathrm{m}$. The treatments (hereafter: Treat $<0.8$, Treat $<10$ and Treat $<50$ ) were prepared by screening the water through either a $0.8 \mu \mathrm{m}$ polycarbonate filter or a 10 or $50 \mu \mathrm{m}$ mesh filter by reverse filtration in order to successively exclude grazers of different sizes (as in Šimek \& Chrzanowski 1992, Jürgens et al. 2000, Verity et al. 2002, Christaki et al. 2001, Sato et al. 2007). Water from each treatment was gently transferred into triplicate 2.51 transparent polycarbonate bottles (Nalgene) by staggered filling using silicone tubing. Another $50 \mathrm{l}$ of seawater was filtered through a $0.2 \mu \mathrm{m}$ sterile Polycap filter and stored in the dark at $1{ }^{\circ} \mathrm{C}$ for later addition to the grazing experiments (a maximum of $8 \mathrm{~d}$ of storage). The $0.2 \mu \mathrm{m}$ filtered water showed no increase in the bacterial or viral abundance during the storage period.

The experimental bottles were incubated on deck in a $1000 \mathrm{l}$ PVC tank in a flow-through water bath pumping water from $5 \mathrm{~m}$ depth to keep the temperature close to in situ surface temperature. The bottles were wrapped in dark nylon mesh, reducing the irradiance to $\sim 30 \%$, similar to the light conditions at the depth at which they were collected. The bottles were kept in motion by the vessel's movements and were rotated daily by hand. Every other day, $260 \mathrm{ml}$ sample (10.6\% of total volume) was removed for the quantification of microorganisms (viruses, bacteria, small phytoplankton, HNF and MZP), chl a (both total $_{i}>0.7 \mu \mathrm{m}$ and $\left.>10 \mu \mathrm{m}\right)$ and nutrients $(\mathrm{N}, \mathrm{P}, \mathrm{Si})$. After each removal, bottles were refilled and diluted with the stored $0.2 \mu \mathrm{m}$ filtered seawater. The experiments lasted $10 \mathrm{~d}$; however, only the first 4 to $6 \mathrm{~d}$ were used for growth and grazing calculations (see Fig. 3).

\section{Enumeration and size of microorganisms}

Viruses, bacteria, pico- and nanophytoplankton and HNF were enumerated using a FACSCalibur (Becton Dickinson) flow cytometer, as described in detail in Paulsen et al. (2015). Phytoplankton were grouped into picoeukaryotes, Synechococcus and nanophytoplankton. Heterotrophs and viruses were stained with a green fluorescent nucleic-acid dye, SYBR Green I (Molecular Probes), and identified on biparametric flow cytometry plots, according to the recommendations of Marie et al. (1999) for viruses and bacteria and Zubkov et al. (2006) for HNF. Bacteria were divided into subgroups of low nucleic acid (LNA) and high nucleic acid (HNA) bacteria. LNA are considered to be less active than the generally larger HNA bacteria (del Giorgio et al. 1996, HueteStauffer \& Morán 2012). Counts and size measurements of larger protists $(>20 \mu \mathrm{m})$, water samples of $500 \mathrm{ml}$ (in situ) or $50 \mathrm{ml}$ (experiments) were gently decanted through a silicone tube into brown glass bottles and fixed in acidic Lugol's solution (final conc.: $3 \%$ ). Cells were counted and sized using an inverted microscope, with the entire sample (or a minimum of 300 cells) quantified. MZP were enumerated during every sampling period in Treat $<50$, and on Days 0 and 10 in Treat<10 only. In addition, the dominant microphytoplankton species in the experiments were identified.

For bacteria, HNF, pico- and nanophytoplankton biomass estimates were based on literature values (fg $\mathrm{C} \mu \mathrm{m}^{-3}$ ), while the biomass of MZP was estimated from their cell volumes and converted into carbon biomass. All biomass conversion factors are given in Paulsen et al. (2015, their Table 1).

\section{Growth and grazing rates}

Net growth rates $\left(\mu, \mathrm{d}^{-1}\right)$ were calculated between each sampling as the change in cell abundance $(N)$ from the diluted abundance at $t_{0}$ to the undiluted sample at $t_{1}$ :

$$
\mu_{n}=\left(\ln N_{1}-\ln N_{0}\right) /\left(t_{1}-t_{0}\right)
$$

where $N_{0}$ is after dilution (at $t_{0}$ ) and $N_{1}$ is before dilution (at $t_{1}$ ), and $n$ is the treatment type (Treat $<0.8$, Treat $<10$ and Treat $<50$ ). Growth rates (see Table 3 ) were calculated based on change in abundance between sampling periods, e.g. Days $0-2$ and 2-4, etc. Growth rates presented here are based on an average of the first days of incubation: Days $0-4$ in Expts II and III and Days 0-6 in Expt I, as growth in Expt I was low due to the winter-like conditions. An exception is bacteria, where growth rate was estimated between Days 2-6 in Expt I and Days 2-4 for Expts II and III, which was necessitated due to an acclimation period between Days 0-2. 
Grazing mortality rates $\left(g, \mathrm{~d}^{-1}\right)$ were estimated from the difference in growth rates of potential prey (HNF, phytoplankton or bacteria) between the grazing reduced treatments, e.g.:

$$
g=\mu_{<0.8}-\operatorname{avg}\left(\mu_{<10}\right)
$$

where the growth rate $\mu_{<0.8}$ from each of the triplicate bottles of Treat $<0.8$ is subtracted by $\operatorname{avg}\left(\mu_{<10}\right)$, the averaged growth in Treat $<10$.

The average prey biomass $C$ during the time between samplings was calculated as in Verity et al. (2002):

$$
C=\left(C_{1}-C_{0}\right) /\left(\ln C_{1}-\ln C_{0}\right)
$$

where $C_{0}$ is the prey biomass after dilution at $t_{0}$ and $C_{1}$ is the prey abundance before dilution at $t_{1}$.

Ingestion rates by heterotrophic protists $(I, \mathrm{mg} \mathrm{C}$ $\mathrm{d}^{-1}$ ) were calculated as:

$$
I=g \times C
$$

where $g$ is the grazing mortality and $C$ is the average prey biomass.

\section{RESULTS}

\section{Field observations}

Throughout the cruise, the station in the Iceland Basin was in the pre-bloom state (Daniels et al. 2015), with stormy weather and wave heights of 3 to $5 \mathrm{~m}$. During the study, day length increased from 11 to $15 \mathrm{~h}$. The water column was initially mixed to $600 \mathrm{~m}$, but the depth of the mixed layer shallowed gradually to $\sim 350 \mathrm{~m}$ during the study period (Fig. 1). Atlantic Water (potential temperature $\theta: 5-10.5^{\circ} \mathrm{C}$, salinity: 35-35.05) was the dominant water mass. During the study, all of the sampled groups of pico- and nanosized organisms were evenly distributed throughout the mixed layer, while large phytoplankton and MZP increased in abundance near the surface. Details on the vertical distribution of microorganisms can be found in Paulsen et al. (2015). The major nutrients $(\mathrm{N}: \mathrm{P}: \mathrm{Si})$ were replete and concentrations largely unchanged, at 13:0.8:5 $\mu \mathrm{M}$ and 12:0.8:4 $\mu \mathrm{M}$ during the first and last visit, respectively.

The mean mixed layer chl a concentration was initially $<0.2 \mu \mathrm{g} \mathrm{chl} \mathrm{a} \mathrm{^{-1 }}$ and gradually increased to $0.6 \mu \mathrm{g} \mathrm{chl} \mathrm{a} \mathrm{l}^{-1}$, with the fraction $<10 \mu \mathrm{m}$ contributing to $>90 \%$ of the chl $a$ on the first sampling. During the latter 2 samplings, chl $a$ in the small $(<10 \mu \mathrm{m})$ fraction was reduced but still contributed, with $\sim 50 \%$ of the total phytoplankton biomass (Fig. 2), and was domi-



Fig. 2. In situ conditions at the station during the 3 sampling occasions. Biomass and size distribution of (A) phytoplankton and (B) heterotrophic protists (heterotrophic nanoflagellates [HNF], heterotrophic dinoflagellates and ciliates) at the sampling station averaged over the mixed layer (by integration and divided by integration depth). Values are shown as mean $\pm \mathrm{SE}(\mathrm{n}=3)$. Right $y$-axis shows averaged abundance of heterotrophic protists within the mixed layer; dots follow same color code as columns

nated by picoeukaryotes $\left(2-5 \times 10^{3}\right.$ cells $\left.\mathrm{ml}^{-1}\right)$ and nanophytoplankton $\left(3-5 \times 10^{2}\right.$ cells $\left.\mathrm{ml}^{-1}\right)$. Synechococcus comprised the lowest autotrophic biomass, however, increasing towards the end of the study and reached a maximum of $5 \times 10^{3} \mathrm{cells} \mathrm{ml}^{-1}$ (equal to 0.17

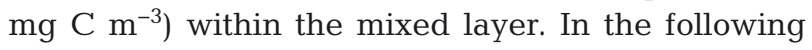
section, we simply use the term picophytoplankton and do not distinguish between Synechococcus and picoeukaryotes, as for the purpose of this study we assume they have the same trophic role as HNF prey.

The bacterial biomass within the mixed layer increased gradually from 3.6 to $5.2 \mathrm{mg} \mathrm{C} \mathrm{m}^{-3}$ on the last sampling occasion. The average abundance of bacteria within the mixed layer ranged from 2 to $4 \times 10^{5}$ cells $\mathrm{ml}^{-1}$, and HNA bacteria became relatively more abundant during the study than LNA bacteria. HNF were measured to have an average equivalent spherical diameter of $3.2 \mu \mathrm{m}$ and increased in abundance from in situ 40 cells ml $^{-1}$ (biomass of $0.08 \mathrm{mg} \mathrm{C} \mathrm{m}^{-3}$ ) 
on the 2 first sampling days to $>200$ cells ml ${ }^{-1}\left(0.93 \mathrm{mg} \mathrm{C} \mathrm{m}^{-3}\right)$ at the end of the study (Fig. 2). In the same period, the MZP more than doubled in biomass from $0.48 \mathrm{mg} \mathrm{C} \mathrm{m}^{-3}$ (1 ciliate and 0.15 dinoflagellate $\left.\mathrm{ml}^{-1}\right)$ to $1.1 \mathrm{mg} \mathrm{C} \mathrm{m}^{-3}(0.4$ ciliate and 0.2 dinoflagellate $\left.\mathrm{ml}^{-1}\right)$, as there was a gradual increase in size, with cells $>30 \mu \mathrm{m}$ becoming more abundant. Heterotrophic dinoflagellates were dominated by species of the genera Gymnodinium, Gyrodinium and Protoperidinium. Ciliates made up 75 to $91 \%$ of the in situ MZP biomass (Fig. 2) and were dominated by aloricate species, mainly strombilids and the mixotrophic Mesodinium rubrum.

\section{Development in the fractionation experiments}

The 3 experiments were initiated with water sampled on 26 March, 11 April and 21 April, respectively. Expt I represented a winter/early pre-bloom community, i.e. initial low abundances of autotrophic and heterotrophic protists (Figs. 2 \& 3). Expts II and III represented the later pre-bloom community, with a more dense microbial community and a more diverse MZP community. The temperature in all experiments approximately followed the in situ sea surface temperature of around

Fig. 3. Development in abundance of microorganisms in the 3 experiments. (A-C) Microzooplankton (MZP) are shown as total heterotrophic dinoflagellates (Dinof.) and ciliates in Treat $<50$ and Treat $<10$; more detailed MZP counts are given in Fig. 4. (D-F) Heterotrophic nanoflagellates (HNF), (G-I) bacteria, (J-L) total chl a, (M-O) nano- and $(\mathrm{P}-\mathrm{R})$ picophytoplankton and $(\mathrm{S}-\mathrm{U})$ viruses are shown from all 3 treatments. (K,L) In addition, the $>10 \mu \mathrm{m}$ chl a fraction is given for Expts II and III. Note: picophytoplankton is the sum of picoeukaryotes and Synechococcus. Values presented as mean $\pm \mathrm{SE}(\mathrm{n}=3)$. Treat $<0.8$, Treat $<10$ and Treat $<50$ indicate use of $0.8,10$ and $50 \mu \mathrm{m}$ mesh filters, respectively. Note the different $y$-axes. Shaded area marks the data used to estimate growth and grazing rates
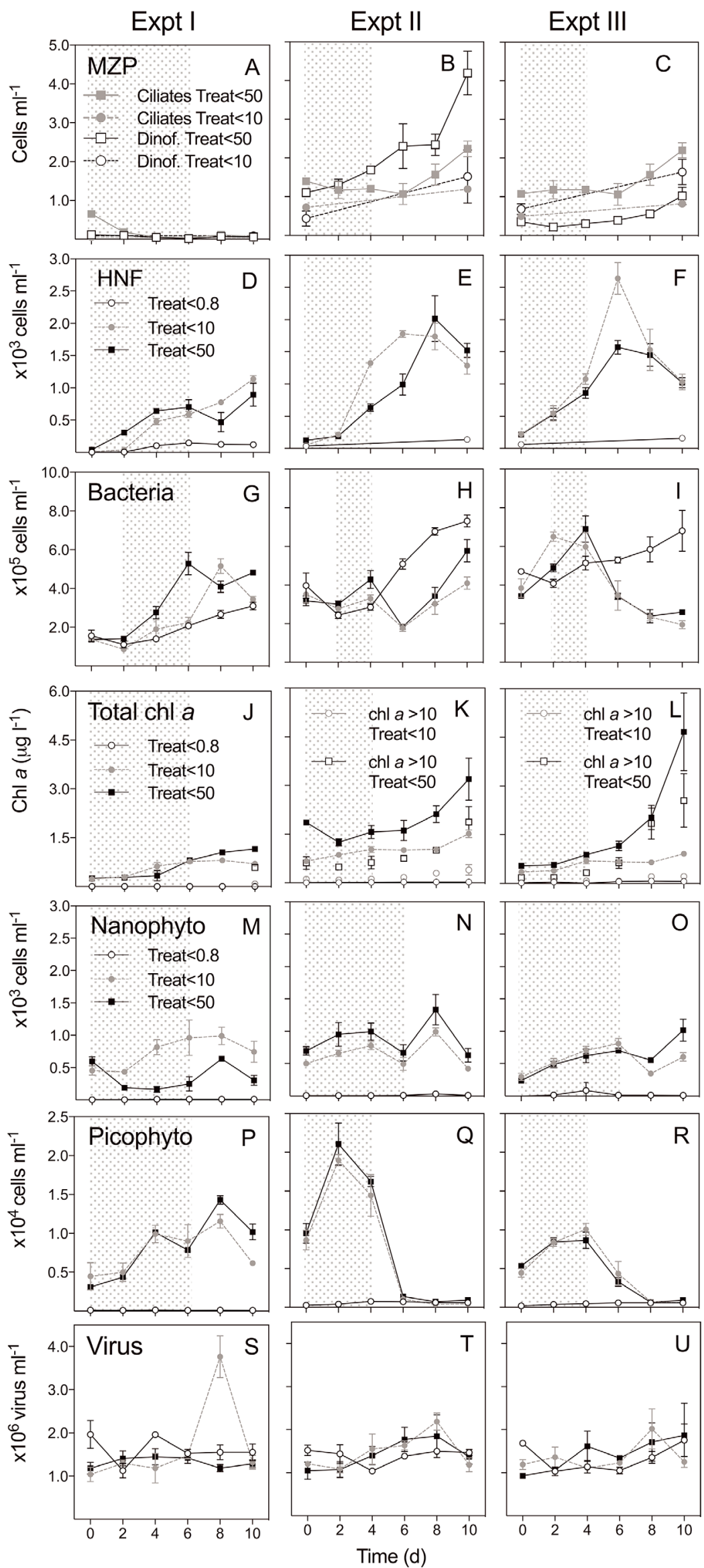
$8^{\circ} \mathrm{C}$. The initial concentrations of the major nutrients $(\mathrm{N}, \mathrm{P}$ and $\mathrm{Si}$ ) were similar for all the experiments (Table 1). During the $10 \mathrm{~d}$ of the experiments, nutrients were utilized according to an increase in chl a. On Day 6, the Si reduction was significantly higher in Treat $<50$ than the other treatments for both Expts I and II and also in Treat $<10$ in Expt II. To ensure that nutrients were unlimited, an additional $<50 \mu \mathrm{m}$ treatment with amendment of nutrients was performed during Expt I (data not shown). The average increase in total chl a was similar between Treat $<50$ and Treat $<50+$ nutrients (1-way ANOVA, $\mathrm{p}>0.05$ ); therefore, we assumed that the phytoplankton growth was not nutrient-limited. This additional treatment was not conducted in the 2 latter experiments, as initial in situ nutrient levels remained replete.

\section{Phytoplankton}

All of the experiments were initiated with low chl a concentrations $\left(<1 \mu \mathrm{g}\right.$ chl $\left.a \mathrm{l}^{-1}\right)$. Chl $a$ in Treat $<50$ incubations was dominated by phytoplankton $<10 \mu \mathrm{m}$ in Expts I and III and by phytoplankton $>10 \mu \mathrm{m}$ in Expt II. Based on microscope observations, we saw that the large chl $a>10 \mu \mathrm{m}$ fraction comprised mainly diatoms, with Chaetoceros spp. dominating in Expt II and Pseudonitzschia spp. in Expt III. This species distribution is consistent with quantification of the initial microphytoplankton community characterized in situ by others (Daniels et al. 2015, Morison \& MendenDeuer 2015). Furthermore, the increase in diatom biomass in Expts II and III is consistent with a reduction in bioavailable $\mathrm{Si}$ of 1.2 and $0.93 \mu \mathrm{M}$, respectively, during the first $6 \mathrm{~d}$, whereas no $\mathrm{Si}$ uptake was evident in Expt I (Table 1).
Expt I had a low initial abundance of grazers, and therefore determining grazing by the fractionation technique was less effective than in the later 2 experiments. In all of the experiments, total chl a increased during the experimental period, but in Expts II and III, the relative increase was significantly higher in Treat $<10$ compared to Treat $<50$ during the first $4 \mathrm{~d}$ (see Table 3). Similarly, the relative increase in picophytoplankton was generally higher in Treat $<0.8$ than in Treat $<10$ in the latter 2 experiments, whereas picophytoplankton showed a slow increase in abundance in all of the treatments during Expt I. Picophytoplankton in Expts II and III was characterized by initial growth followed by an abrupt decrease during Days 4-6 in Treat $<10$ and Treat $<50$, while having a steady increase throughout the experimental period in Treat $<0.8$ (Fig. 3P-R). The development in nanophytoplankton and chl a did not show the same successional pattern as picophytoplankton and could best be described as an irregular increase in both Treat $<10$ and Treat $<50$ (Fig. 3). Surprisingly, we saw relatively high growth of nanophytoplankton in Treat $<10$ compared to Treat $<50$ in Expt I (Fig. 4) even though abundances of MZP were low (if there was no MZP grazing, nanoplankton would grow equally well in Treat $<10$ and Treat $<50$ ). This may be explained by the fact that there were no larger phytoplankton present and thus HNF and nanophytoplankton exclusively sustained the MZP in Treat $<50$, while in Expts II and III, the presence of larger phytoplankton relaxed the pressure on nanoplankton.

\section{Bacteria and viruses}

In Expt I, bacteria increased in abundance in all treatments after Day 2. In Expts II and III, the net

Table 1. Concentration $(\mu \mathrm{M})$ of nutrients initially and after $6 \mathrm{~d}$. Start values are given as mean \pm SD $(n=9)$, while end values are given for each treatment $(n=3)$. Treat $<0.8$, Treat $<10$ and Treat $<50$ indicate use of $0.8,10$ and $50 \mu \mathrm{m}$ mesh filters, respectively. ${ }^{*}$ Significant difference between treatments (ANOVA, $\mathrm{p}<0.005$ )

\begin{tabular}{|c|c|c|c|c|c|c|c|}
\hline & \multirow{2}{*}{$\begin{array}{l}\text { Nutrients } \\
\qquad(\mu \mathrm{M})\end{array}$} & \multicolumn{2}{|c|}{- Expt I -} & \multicolumn{2}{|c|}{- Expt II -} & \multicolumn{2}{|c|}{ Expt III } \\
\hline & & Initial & After $6 \mathrm{~d}$ & Initial & After $6 \mathrm{~d}$ & Initial & After $6 \mathrm{~d}$ \\
\hline $\mathrm{NO}_{3}^{-}+\mathrm{NO}_{2}^{-}$ & $\begin{array}{l}\text { Treat }<0.8 \\
\text { Treat }<10 \\
\text { Treat }<50\end{array}$ & $12.3 \pm 0.3$ & $\begin{array}{l}12.1 \pm 0.2 \\
12.0 \pm 0.3 \\
11.9 \pm 0.1\end{array}$ & $12.0 \pm 0.3$ & $\begin{aligned} 10.9 & \pm 0.1 \\
10.2 & \pm 0.2 \\
8.4 & \pm 0.8^{*}\end{aligned}$ & $11.6 \pm 0.2$ & $\begin{array}{l}11.7 \pm 0.07 \\
11.1 \pm 0.04 \\
10.4 \pm 0.04^{*}\end{array}$ \\
\hline $\mathrm{PO}_{4}^{+}$ & $\begin{array}{l}\text { Treat }<0.8 \\
\text { Treat }<10 \\
\text { Treat }<50\end{array}$ & $0.9 \pm 0.4$ & $\begin{array}{l}1.0 \pm 0.04 \\
0.9 \pm 0.02 \\
0.8 \pm 0.01\end{array}$ & $0.77 \pm 0.1$ & $\begin{array}{l}0.72 \pm 0.01^{*} \\
0.59 \pm 0.01^{*} \\
0.45 \pm 0.04^{*}\end{array}$ & $0.74 \pm 0.02$ & $\begin{array}{r}0.76 \pm 0.01 \\
0.74 \pm 0.01 \\
0.6 \pm 0.03^{*}\end{array}$ \\
\hline $\mathrm{Si}$ & $\begin{array}{l}\text { Treat }<0.8 \\
\text { Treat }<10 \\
\text { Treat }<50\end{array}$ & $4.6 \pm 0.1$ & $\begin{array}{l}4.7 \pm 0.04 \\
4.7 \pm 0.06 \\
4.6 \pm 0.01\end{array}$ & $3.9 \pm 0.1$ & $\begin{array}{l}4.1 \pm 0.02 \\
3.5 \pm 0.09^{*} \\
2.7 \pm 0.26^{*}\end{array}$ & $4.23 \pm 0.05$ & $\begin{array}{l}4.3 \pm 0.01 \\
4.1 \pm 0.02 \\
3.3 \pm 0.3^{*}\end{array}$ \\
\hline
\end{tabular}




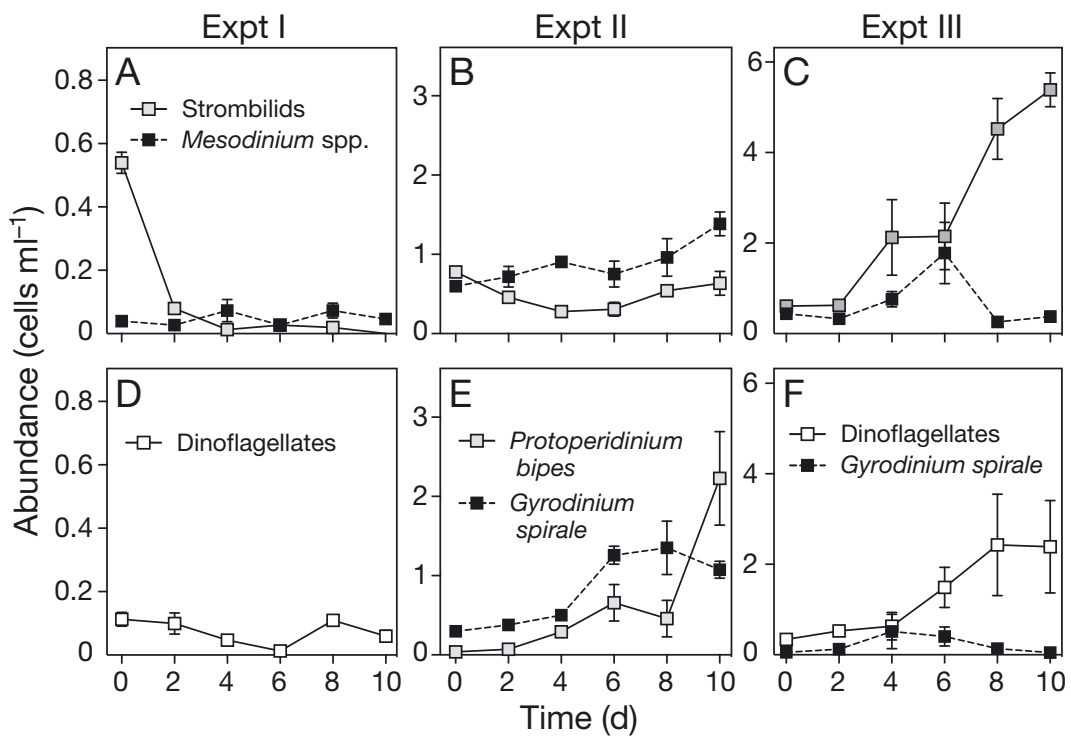

Fig. 4. Development in abundance of the dominating (A-C) ciliates and (D-F) dinoflagellates in Treat $<50$ (use of $50 \mu \mathrm{m}$ mesh filters) in the 3 microcosm experiments (Note: total abundance of dinoflagellates is given when no species were particularly dominating). Values presented as mean $\pm \operatorname{SE}(n=3)$. Note the different $y$-axes between experiments growth of bacteria in Treat $<10$ and Treat $<50$ was variable, while the bacterial abundance increased continuously in Treat $<0.8$ in all experiments. In Expt III, bacteria increased in abundance during Days $2-4$, but after Day 4, they decreased exponentially in Treat $<10$ and Treat $<50$, similar to picophytoplankton, indicating HNF grazing on both groups. In Expt II, bacteria similarly decreased from Days 4-6, but then increased again. When divided into HNA and LNA groups of bacteria (Fig. 5A-C), it is apparent that it is the more active HNA that drives the increase in Treat $<0.8$. The abundance of viruses was generally constant within the range of $1-2 \times 10^{6}$ cells ml ${ }^{-1}$ throughout all of the experiments (Fig. 3S-U), with a single high peak $\left(>3 \times 10^{6} \mathrm{ml}^{-1}\right)$ in Expt I. The virus:bacteria (V:B) ratio tended to drop (Fig. 5D-F) according to an increase in bacteria and vice versa (Fig. 3G-I).

\section{Heterotrophic protists}

Initially, HNF abundances were low in all the experiments, e.g. Treat $<50$ contained $43 \pm 10,126 \pm 30$ and $217 \pm$ $31 \mathrm{HNF} \mathrm{ml}^{-1}$ in Expts I, II and III, respectively. The greatest increase in HNF was in Treat $<10$, from initially $<100$ cells ml ${ }^{-1}$ to up to 3000 cells ml ${ }^{-1}$. Abundances decreased during the last 3 to $4 \mathrm{~d}$ of the incubation period of Expts II and III. All of the experiments were initiated with low abundances of MZP $\left(<2\right.$ cells $\left.\mathrm{ml}^{-1}\right)$. In Expt $\mathrm{I}$, the abundance remained low throughout the incubation period, whereas in Expts II and III, the MZP abundance increased moderately, with an average growth rate of $0.1 \mathrm{~d}^{-1}$ during the incubation period, reaching a maximum of around 5 cells $\mathrm{ml}^{-1}$ after $10 \mathrm{~d}$. The highest abundance was that of dinoflagellates in Expt II (the only experiment where Chaetoceros spp. became abundant), where the small thecate Protoperidinium bipes dominated along with the naked Gymnodinium spirale (Fig. 4D-F). In Expts I and III, dinoflagellates were numerically dominated by small unidentified naked dinoflagellates, most likely gymnodoid species. Ciliates were dominated by Mesodinium rubrum and spirotrichs, primarily the genera Strombidium and Strobilidium (Fig. 4A-C). In Expt II, on the last sampling day, the MZP biomass in Treat $<10$ was on average $16 \pm 7 \%$ of the biomass in Treat $<50$. Although MZP was present in Treat $<10$,
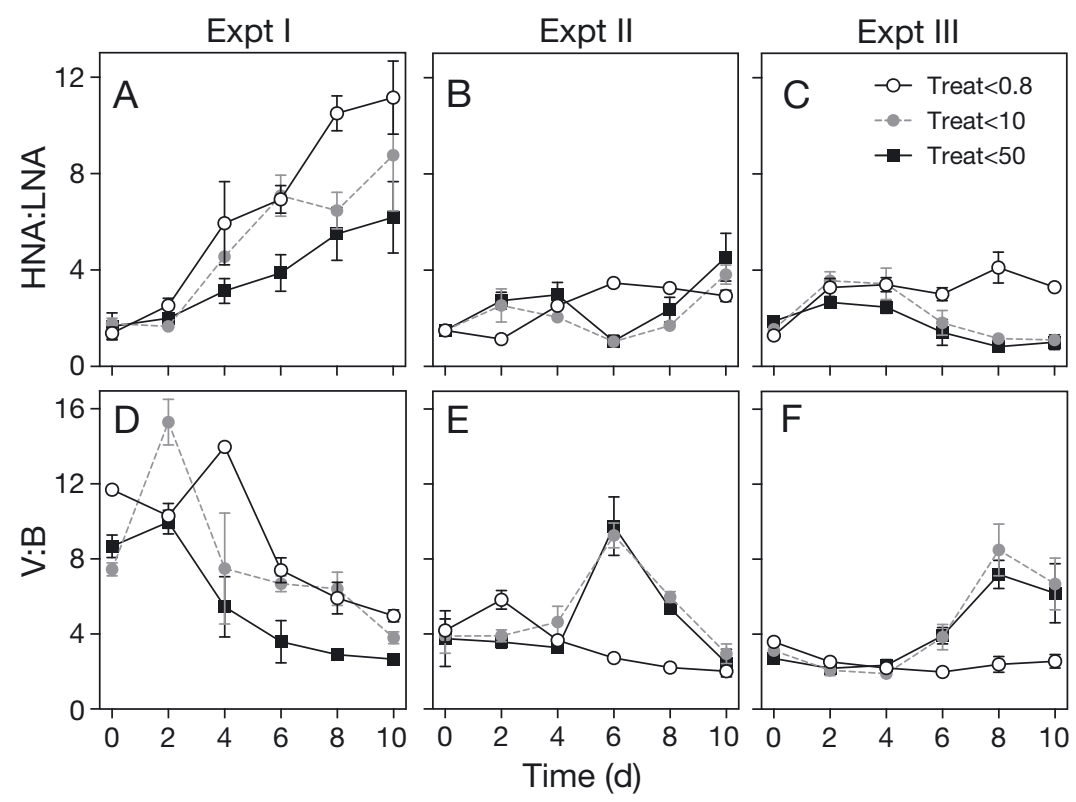

Fig. 5. Development in ratio of (A-C) high nucleic acid (HNA) to low nucleic acid (LNA) bacteria and (D-F) viruses to bacteria (V:B) abundance. Treat $<0.8$, Treat $<10$ and Treat $<50$ indicate use of $0.8,10$ and $50 \mu \mathrm{m}$ mesh filters, respectively. Values are given as mean $\pm \mathrm{SE}(\mathrm{n}=3)$ for the 3 experiments 
their size was smaller and the biomass was markedly reduced compared to Treat $<50$ (Table 2). MZP biomass in Treat $<10$ was primarily composed of dinoflagellates (Gyrodinium spirale and small unidentified gymnodoid species), but some small (equivalent spherical diameter: 10-12 $\mu \mathrm{m})$ Mesodinium spp. were also present in low numbers $\left(<0.5 \mathrm{cells} \mathrm{ml}^{-1}\right)$. No large $(>20 \mu \mathrm{m})$ ciliates were present in any of the Treat $<10$ incubations.

\section{Growth and grazing mortality}

For all 3 experiments, the growth rate of picophytoplankton in the ungrazed treatments (Treat<0.8) ranged from 0.10 to $0.32 \mathrm{~d}^{-1}$ (mean: $0.22 \mathrm{~d}^{-1}$ ). In Treat $<10$, where MZP abundance was reduced, nanophytoplankton grew at a similar rate as picophytoplankton, ranging from 0.17 to $0.23 \mathrm{~d}^{-1}$ (mean: $0.22 \mathrm{~d}^{-1}$ ). HNF grew with the highest growth rates in the range 0.43 to $0.84 \mathrm{~d}^{-1}$ in Treat $<10$ and slightly reduced in Treat $<50$, at 0.30 to $0.43 \mathrm{~d}^{-1}$ (Table 3). The second highest growth was that of bacteria; notice however that the highest bacterial growth was not found in the grazer-reduced Treat $<0.8$ (Table 3).

The difference in growth rates between fractions is here considered to be due to grazing mortality by heterotrophic protists, estimated by Eq. (2) and summarized in Table 4. In Expts I and II, the mortality of HNF was positive (i.e. there was a grazing loss) and corresponded to 30 and $48 \% \mathrm{~d}^{-1}$ of their growth rate in absence of a predator, respectively. In Expts II and III, a low grazing mortality on picophytoplankton was observed during the first $4 \mathrm{~d}$, whereas grazing mortality on nanophytoplankton was only observed in Expt I in Treat $<50$. Grazing of total chl a was near zero in Expts I and II during the first $4 \mathrm{~d}$, and only in Expt III was growth higher in Treat<10 than Treat $<50$, resulting in grazing rates of 0.14 and $0.18 \mathrm{~d}^{-1}$ for chl $a<10$ and $>10 \mu \mathrm{m}$, respectively (Table 4). Grazing mortality for large-sized phytoplankton (chl $a>10 \mu \mathrm{m}$ ) was only observed in Expt III, the last conducted experiment.

The HNF ingestion rate (I, $\mathrm{mg} \mathrm{C} \mathrm{d}^{-1}$ ) (Eq. 4) of prey biomass (Eq. 3), given a biomass of 0.02, 0.17 and $0.57 \mathrm{pg} \mathrm{C}$ cell $^{-1}$ for bacteria, Synechococcus and picoeukaryotes, respectively (from Paulsen et al. 2015), showed that picophytoplankton satisfied up to $70 \%$ of the total carbon uptake of HNF in Expt II, which had the highest initial concentration of picophytoplankton. However, in Expt III, bacteria comprised the main carbon source, while picophytoplankton only comprised 17 to $37 \%$. The average ingestion rate of HNF in cell numbers was 4 bacteria

Table 2. Average abundance (cells $\mathrm{ml}^{-1}$ ) and biomass $\left(\mathrm{mg} \mathrm{C} \mathrm{m}^{-3}\right)$ of microorganisms during the period used for growth and grazing estimation (Fig. 3), given for each treatment as mean \pm SD $(n=3)$. Treat $<0.8$, Treat $<10$ and Treat $<50$ indicate use of $0.8,10$ and $50 \mu m$ mesh filters, respectively. HNF = heterotrophic nanoflagellates

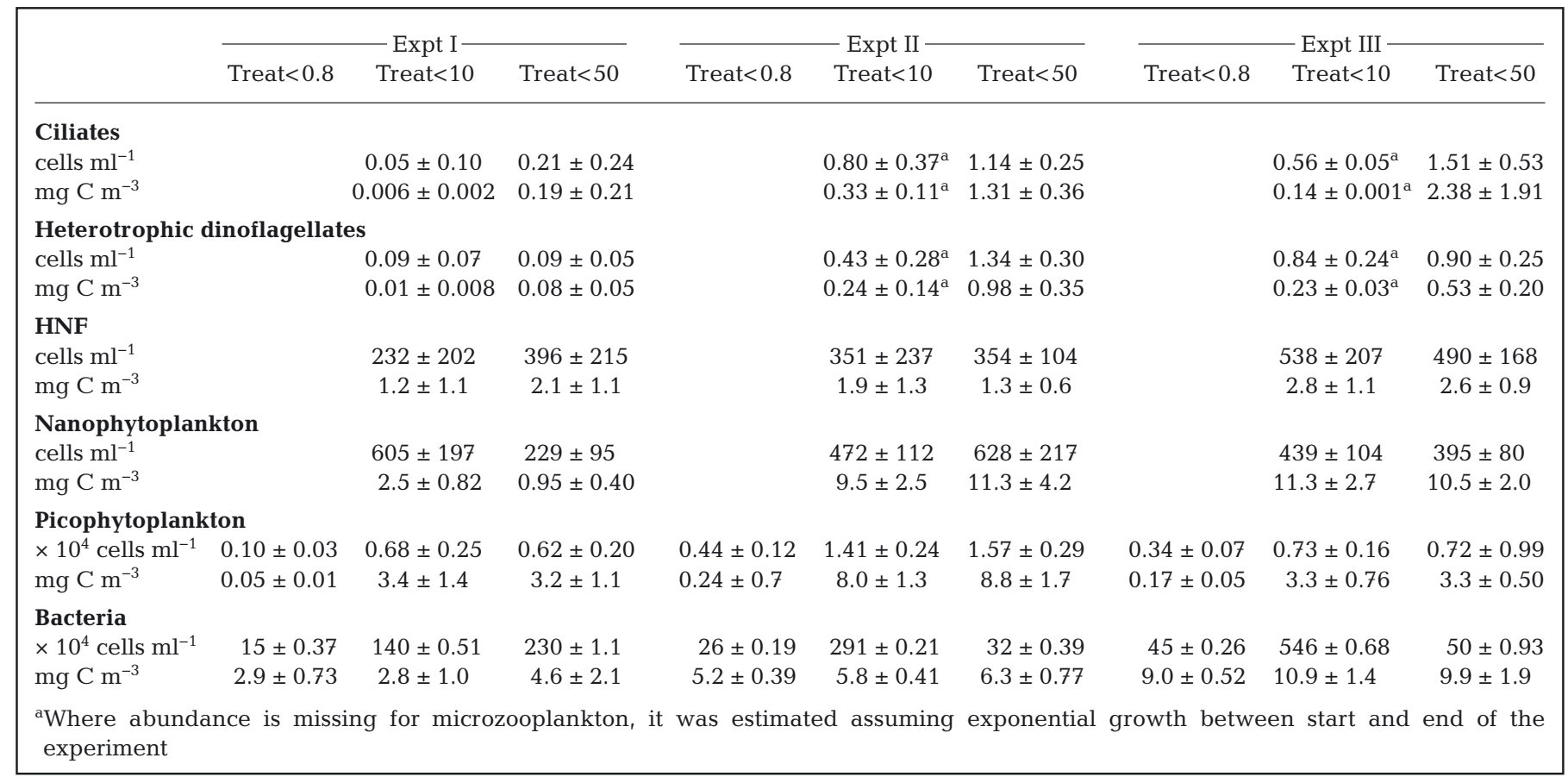


Table 3. Net growth rates $\left(\mu, d^{-1}\right)$ of microorganisms obtained from Days 0-6 (Expt $\mathrm{I}, \mathrm{n}=9$ ), except for bacteria, where growth rate was estimated from Days 2-4 in all 3 experiments, and Days 0-4 (Expts II and III, $\mathrm{n}=6$ ). Values are given as mean \pm SD. Subscript to $\mu$ indicates treatment type (use of 0.8, 10 and $50 \mu \mathrm{m}$ mesh filters, respectively). HNF = heterotrophic nanoflagellates. ${ }^{*}$ Significant difference between fractionation treatments (ANOVA, $\mathrm{p}<0.005)$

\begin{tabular}{|c|c|c|c|c|c|c|c|c|c|}
\hline & \multicolumn{3}{|c|}{-Expt I } & \multicolumn{3}{|c|}{ - Expt II } & \multicolumn{3}{|c|}{ - Expt III - } \\
\hline & $\mu_{<0.8}$ & $\mu_{<10}$ & $\mu_{<50}$ & $\mu_{<0.8}$ & $\mu_{<10}$ & $\mu_{<50}$ & $\mu_{<0.8}$ & $\mu_{<10}$ & $\mu_{<50}$ \\
\hline Ciliates & & & $-0.81 \pm 0.24$ & & & $-0.01 \pm 0.21$ & & & $0.08 \pm 0.14$ \\
\hline Dinoflagellates & & & $-0.21 \pm 0.54$ & & & $0.16 \pm 0.10$ & & & $0.20 \pm 0.20$ \\
\hline HNF & & $0.43 \pm 0.28$ & $0.30 \pm 0.24$ & & $0.84 \pm 0.13^{*}$ & $0.43 \pm 0.25^{*}$ & & $0.45 \pm 0.19$ & $0.40 \pm 0.15$ \\
\hline Nanophytoplankton & & $0.17 \pm 0.22^{*}$ & $-0.12 \pm 0.38^{*}$ & & $0.22 \pm 0.33$ & $0.31 \pm 0.32$ & & $0.23 \pm 0.10$ & $0.23 \pm 0.17$ \\
\hline Total chl a & & $0.24 \pm 0.19$ & $0.23 \pm 0.14$ & & $0.17 \pm 0.05^{*}$ & $-0.004 \pm 0.19^{*}$ & & $0.34 \pm 0.07$ & $0.19 \pm 0.09$ \\
\hline Chl $a<10 \mu \mathrm{m}$ & & $0.24 \pm 0.19$ & $0.23 \pm 0.14$ & & $0.14 \pm 0.03$ & $0.17 \pm 0.05$ & & $0.36 \pm 0.06^{*}$ & $0.22 \pm 0.05^{*}$ \\
\hline Chl $a>10 \mu \mathrm{m}$ & & & & & $0.16 \pm 0.36$ & $0.13 \pm 0.18$ & & $0.15 \pm 0.06$ & $0.18 \pm 0.09$ \\
\hline Picophytoplankton & $0.10 \pm 0.37$ & $0.17 \pm 0.27$ & $0.19 \pm 0.23$ & $0.32 \pm 0.08^{*}$ & $0.18 \pm 0.30$ & $0.19 \pm 0.27$ & $0.25 \pm 0.14$ & $0.23 \pm 0.10$ & $0.14 \pm 0.11$ \\
\hline Bacteria & $0.22 \pm 0.10$ & $0.29 \pm 0.23$ & $0.38 \pm 0.08$ & $0.17 \pm 0.06$ & $0.14 \pm 0.06$ & $0.23 \pm 0.03$ & $0.13 \pm 0.02 *$ & $-0.05 \pm 0.09^{*}$ & $0.23 \pm 0.03^{*}$ \\
\hline
\end{tabular}

Table 4. Estimated grazing mortality rates $\left(g, \mathrm{~d}^{-1}\right)$ of microorganisms calculated as difference in growth rates $\left(\mu_{<0.8}, \mu_{<10}, \mu_{<50} ;\right.$ Table 3) obtained in the fractionation treatments (use of 0.8, 10 and $50 \mu \mathrm{m}$ mesh filters, respectively). Values are given as mean \pm SD during Days 0-6 (Expt I) and Days 0-4 (Expts II and III). HNF = heterotrophic nanoflagellates

\begin{tabular}{|c|c|c|c|c|c|c|}
\hline & \multicolumn{2}{|c|}{$\longrightarrow$ Expt I } & \multicolumn{2}{|c|}{$\longrightarrow$ Expt II $\longrightarrow$} & \multicolumn{2}{|c|}{$\longrightarrow$ Expt III } \\
\hline & $\mu_{<0.8}-\mu_{<10}$ & $\mu_{<10}-\mu_{<50}$ & $\mu_{<0.8}-\mu_{<10}$ & $\mu_{<10}-\mu_{<50}$ & $\mu_{<0.8}-\mu_{<10}$ & $\mu_{<10}-\mu_{<50}$ \\
\hline $\mathrm{HNF}$ & & $0.13 \pm 0.29$ & & $0.41 \pm 0.16$ & & $-0.03 \pm 0.29$ \\
\hline Nanophytoplankton & & $0.29 \pm 0.39$ & & $-0.08 \pm 0.11$ & & $-0.01 \pm 0.12$ \\
\hline Chl $a<10 \mu \mathrm{m}$ & & $0.01 \pm 0.11$ & & $-0.03 \pm 0.05$ & & $0.14 \pm 0.05$ \\
\hline Chl $a>10 \mu \mathrm{m}$ & & & & $-0.01 \pm 0.09$ & & $0.18 \pm 0.09$ \\
\hline Picophytoplankton & $-0.08 \pm 0.29$ & $0.07 \pm 0.24$ & $0.20 \pm 0.28$ & $0.07 \pm 0.21$ & $0.02 \pm 0.13$ & $0.09 \pm 0.05$ \\
\hline Bacteria & $-0.07 \pm 0.25$ & $-0.09 \pm 0.14$ & $0.19 \pm 0.09$ & $-0.28 \pm 0.03$ & $0.03 \pm 0.05$ & $-0.09 \pm 0.03$ \\
\hline
\end{tabular}

and 0.2 picophytoplankton $\mathrm{h}^{-1}$. The ingestion of bacteria was within the range obtained in other studies (Bjørnsen et al. 1988, Christaki et al. 2001, Vaqué et al. 2008), and that of picophytoplankton was within an order of magnitude of those reported by Christaki et al. (2005).

\section{Regression analysis of predator-prey relationships}

\section{HNF grazing on picoplankton}

Growth and biomass data between each sampling from Expts II and III (Treat<10) were used for regression analysis to evaluate the grazing mortality of picophytoplankton due to HNF. Data from Expt I were not included, as this experiment was still in the winter state and grazing on picoplankton was close to zero (Table 4). Regression analysis revealed a significant positive correlation of HNF growth rate and picophytoplankton biomass $\left(\mathrm{mg} \mathrm{C} \mathrm{m}^{-3}\right)$, and the growth of HNF increased linearly with a rate of $0.12 \mathrm{mg} \mathrm{C} \mathrm{m}^{-3} \mathrm{~d}^{-1}$ (i.e. the slope of regression line slope) $\left(r^{2}=0.80, p<0.0001\right.$; Fig. 6A). No growth sat- uration for HNF growth was found within the range of picophytoplankton biomass $\left(0.2-10 \mathrm{mg} \mathrm{C} \mathrm{m}^{-3}\right)$. The mortality rate of picophytoplankton due to HNF grazing was estimated from the slope of a linear regression fitted to the HNF biomass (mg $\mathrm{C} \mathrm{m}^{-3}$ ) against the picophytoplankton growth rate $\left(\mathrm{d}^{-1}\right)$ (Fig. 6B). The regression resulted in a significant negative relationship $\left(\mathrm{r}^{2}=0.50, \mathrm{p}<0.0001, \mathrm{n}=30\right)$ and a loss rate due to grazing of $0.12 \mathrm{mg} \mathrm{C} \mathrm{m}^{-3} \mathrm{~d}^{-1}$. Neither bacterial biomass versus HNF growth $\left(\mathrm{r}^{2}=0.05, \mathrm{p}=\right.$ $0.24)$ nor HNF biomass versus bacterial growth $\left(\mathrm{r}^{2}=\right.$ 0.003, $\mathrm{p}=0.81$ ) correlated (data not shown).

Having found a significant relationship between HNF growth rate and picophytoplankton biomass, we can calculate the HNF weight-specific clearance rate $(F)$ as:

$$
\mu=(F \times e) C_{\text {prey }}
$$

where $\mu$ is HNF growth rate $\left(\mathrm{d}^{-1}\right)$, $e$ is the growth efficiency, $C_{\text {prey }}$ is the picophytoplankton biomass $\left(\mathrm{mg} \mathrm{C} \mathrm{m}{ }^{-3}\right)$ and $(F \times e)$ is the slope of the regression $\left(0.12 \mathrm{mg} \mathrm{C} \mathrm{m}^{-3} \mathrm{~d}^{-1}\right)$. Assuming an e of $30 \%$ (Fenchel 1982), this results in an HNF weight specific clearance of: 

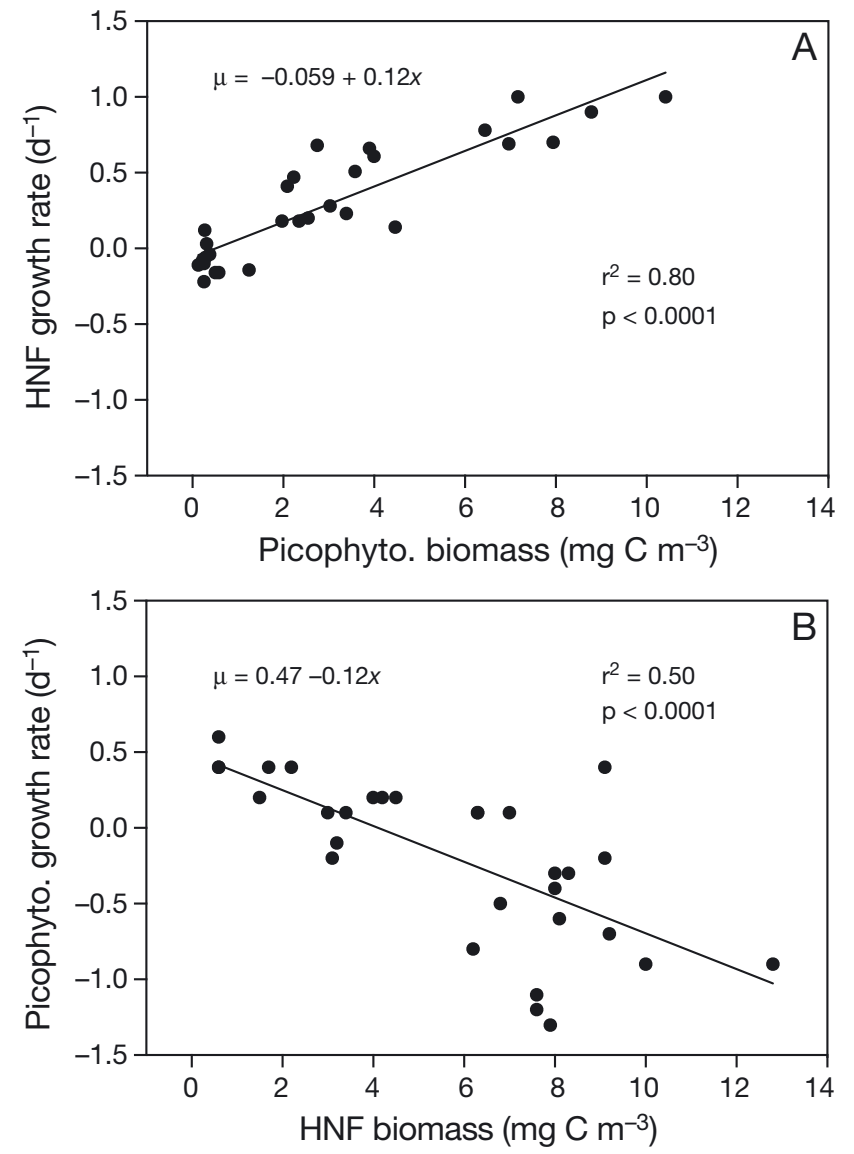

Fig. 6. Growth rates $\left(\mu, d^{-1}\right)$ of $(A)$ heterotrophic nanoflagellates (HNF) as a function of picophytoplankton biomass, and (B) picophytoplankton as a function of HNF biomass. $\mu$ values were estimated from Expts II and III (Treat<10, i.e. use of $10 \mu \mathrm{m}$ mesh filters)

$$
F=0.12 \mathrm{~m}^{-3} \mathrm{~d}^{-1} \mathrm{mg} \mathrm{C}^{-1} / 0.30=0.4 \mathrm{~m}^{-3} \mathrm{~d}^{-1} \mathrm{mg} \mathrm{C}^{-1}
$$

When applying an HNF carbon to body volume conversion factor of $0.12 \mathrm{pg} \mathrm{C} \mathrm{m}{ }^{-3}$ (Fenchel 1982), this yields a specific clearance rate of $\sim 10^{6}$ body volumes $\mathrm{h}^{-1}$. HNF are known to collect prey with a high efficiency and have previously been found to clear the prey particles from at least $10^{5}$ body volumes $\mathrm{h}^{-1}$ (Fenchel 1982, Hansen et al. 1997).

\section{MZP grazing on nanoplankton}

The nanoplankton (HNF and nanophytoplankton) were assumed to be grazed mainly by ciliates. The nanophytoplankton and HNF net growth rates estimated from Expts II and III (from Treat <50) were plotted against ciliate biomass between each sampling to evaluate the importance of ciliates as grazers.
There was no significant relationship between nanophytoplankton biomass and ciliate net growth rate $\left(\mathrm{r}^{2}\right.$ $=0.004, \mathrm{p}=0.76$ ) or between ciliate biomass and nanophytoplankton net growth rate $\left(\mathrm{r}^{2}=0.006\right.$, $\mathrm{p}=0.71$ ) (data not shown). However, a significant relationship was found between HNF biomass and ciliate net growth rate $\left(r^{2}=0.26, p=0.0063\right.$; Fig. $\left.7 \mathrm{~A}\right)$. The hypothesis of ciliates being major grazers on HNF was supported by a negative relationship between ciliate biomass and HNF growth rate $\left(\mathrm{r}^{2}=0.28, \mathrm{p}=\right.$ 0.0046; Fig. 7B), where the slope indicated an average specific HNF mortality of $0.12 \mathrm{mg} \mathrm{C} \mathrm{m}^{-3} \mathrm{~d}^{-1}$.

\section{DISCUSSION}

Microbial communities have been studied during the spring bloom, e.g. during the North Atlantic bloom experiment (Ducklow et al. 1993, Li et al.
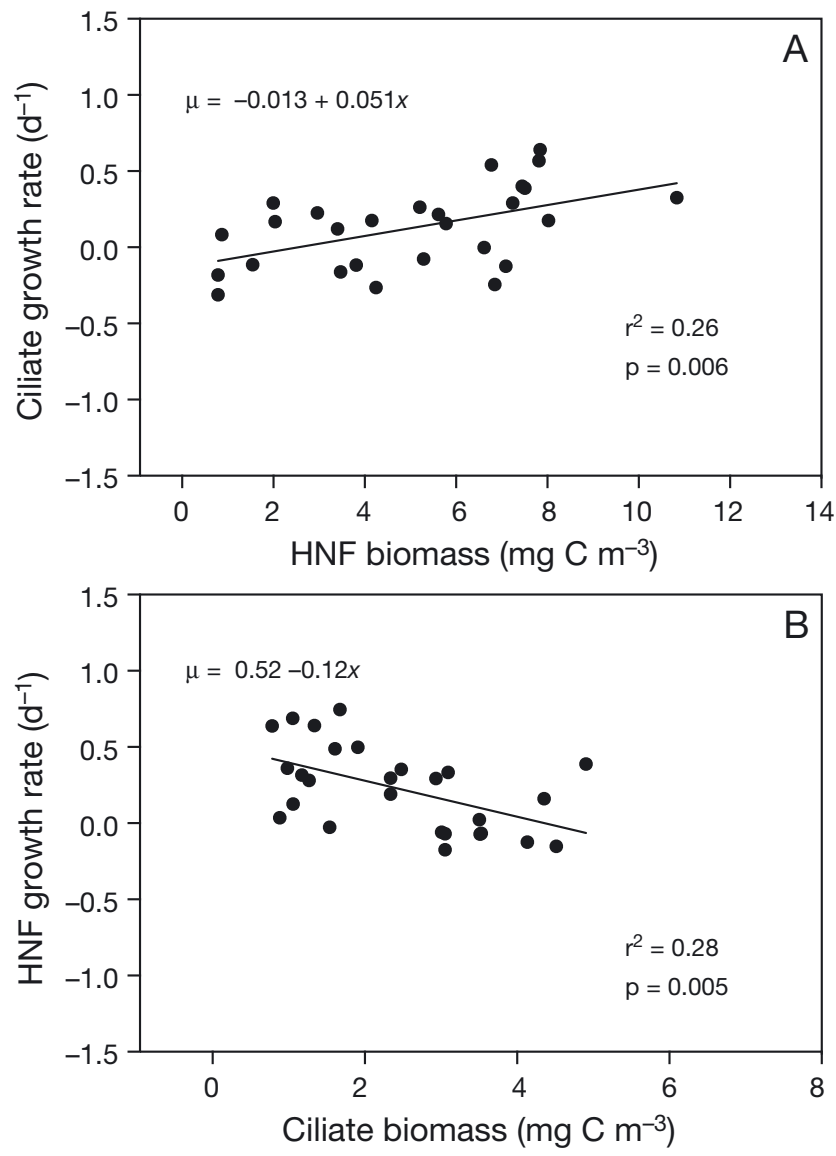

Fig. 7. Growth rates $\left(\mu, d^{-1}\right)$ of (A) ciliates as a function of heterotrophic nanoflagellates (HNF) biomass and (B) HNF as a function of ciliate biomass. Values were estimated from Expts II and III (Treat<50, i.e. use of $50 \mu \mathrm{m}$ mesh filters). Linear regression lines: (A) $\mu=-0.13+0.051 x$, and (B) $\mu=$ $0.52-0.12 x$. Number of data points, $n=30$ 
1993, Verity et al. 1993). However, there is limited knowledge regarding the microbial plankton communities during the winter-spring transition, primarily because it is assumed that the spring bloom initiates the productive cycle. Paulsen et al. (2015) and the present study document the presence of an active microbial community within the deep mixed layer of the Iceland Basin prior to the spring bloom. Production was initially driven by pico- and nano-sized phytoplankton, but during the pre-bloom period, the nano- and microphytoplankton became increasingly important. Observations such as these are essential for our understanding of the biological processes regulating spring bloom development. Furthermore, our results underline the importance of pico- and nanosized phytoplankton for boosting both the bacterial and the heterotrophic protist communities dominated by HNF and ciliates prior to the spring bloom.

\section{Methodological limitations}

The fractionation technique has previously been used to estimate growth and grazing rates of microorganisms and has been validated via comparisons with other methods (Christaki et al. 2001). Here, we discuss the limitations of our approach before discussing our results any further. Firstly, the fractionation technique did not include the grazing of MZP by mesozooplankton. Secondly, the filters did not separate all functional groups, and they did not entirely separate organisms of the intended size, particularly the elongated dinoflagellates $>10 \mu \mathrm{m}$ that ended up in the $<10 \mu \mathrm{m}$ fractions. This generally leads to an underestimation of grazing rates (Verity et al. 1993). However, based on the estimated MZP biomass in the $<10 \mu \mathrm{m}$ treatments, which was on average $80 \%$ smaller than in Treat $<50$, we assumed the underestimation was minor.

Thirdly, incubating the experimental bottles on deck and thereby increasing light compared to in situ conditions can increase growth rates and thus underestimate grazing rates of phytoplankton. Finally, there is the issue that the filtration process may damage the cells, thereby increasing the concentration of bioavailable dissolved organic carbon (BDOC) or releasing allelochemicals that may inhibit or stimulate growth of other organisms (Pree et al. 2016). A higher release of labile carbon would result in a higher bacterial growth in the treatments where screening was done using fine mesh filters compared with the treatments in which coarse mesh filters were used. However, labile DOC is usually assimilated within hours to days (Hansell 2013), and as the bacterial growth was only positive after $\sim 2 \mathrm{~d}$, we assume that bacterial growth was not accelerated by labile DOC. Therefore, despite limitations, we found the fractionation technique appropriate for studying dilute pre-bloom systems dominated by small phytoplankton.

\section{Importance of HNF grazing}

HNF had the highest net growth rates of the microbes investigated in situ (Paulsen et al. 2015) and in the present experiments. Although HNF did not contribute substantially to the biomass of heterotrophic protists during the first days of the experiments, their growth rates exceeded that of MZP, and on average had a biomass similar to MZP (Table 2). The high growth rates of HNF and a specific clearance rate of $\sim 10^{6}$ body volumes $\mathrm{h}^{-1}$ further suggested a high grazing potential of HNF during the winterspring transition. The linear regression of the HNF community growth rate versus the picophytoplankton biomass (Fig. 6A) can be used to estimate HNF growth at a given picophytoplankton biomass, e.g. an HNF growth rate of $0.21 \mathrm{~d}^{-1}$ was found when the biomass of picophytoplankton was $2.2 \mathrm{mg} \mathrm{C} \mathrm{m}^{-3}$ (the in situ average during the last 2 sampling occasions). This equals an HNF production rate of $1.3 \mathrm{pg} \mathrm{C} \mathrm{d}^{-1}$, given a cell carbon content of $4.5 \mathrm{pg} \mathrm{C}$ cell $^{-1}$ (Børsheim \& Bratbak 1987). At $30 \%$ growth efficiency (Fenchel 1982), this gives a carbon demand of $4.4 \mathrm{pg}$ $\mathrm{C} \mathrm{d}^{-1}$, which equals 9 bacteria $\mathrm{h}^{-1}$, assuming a carbon content of $20 \mathrm{fg}$ bacteria $^{-1}$ (Lee \& Fuhrman 1987). Given our estimated ingestion rate of bacteria (max. 4 bacteria $\mathrm{h}^{-1}$ ), the consumption of bacteria would only satisfy $\sim 1 / 3$ of the carbon demand. The remaining carbon demand would equal the ingestion of 0.24 picophytoplankton $\mathrm{h}^{-1}$, which was close to the HNF ingestion rate of 0.21 picophytoplankton $\mathrm{h}^{-1}$ that we found in our experiments (average of Expts II and III), thus confirming that the carbon demand of HNF was satisfied by bacteria and to a high degree of picophytoplankton, grazing up to $65 \%$ picophytoplankton production (1.6 $\mathrm{mg} \mathrm{C} \mathrm{m}^{-3} \mathrm{~d}^{-1}$ ).

\section{Comparison with dilution experiment results}

An inherent challenge when estimating growth and grazing is choosing the period for growth rate estimation, as this may change during the course of the experiment. Here we evaluated rates within the 
initial 4 to $6 \mathrm{~d}$ of incubation to calculate rates, whilst data from the full $10 \mathrm{~d}$ were used for the regression analysis. However, the dilution experiments that were performed simultaneously by Morison \& MendenDeuer (2015) used only $24 \mathrm{~h}$ incubation. When comparing the grazing results from the cruise, Morison \& Menden-Deuer (2015) found a grazing rate of $50 \pm$ $30 \%$ of the daily primary production (at the Iceland Basin station), which is comparable to our estimated HNF grazing of up to $65 \%$ of the daily picophytoplankton production. Our results therefore suggest that the relationship between chl a growth and grazing found by Morison \& Menden-Deuer (2015) through 15 dilution experiments could be a result of a tight coupling between HNF and picophytoplankton. Further, Morison \& Menden-Deuer (2015) did not find reduced grazing with increasing mixed layer depth as was expected. This can be explained partly by our observations, as we found that HNF, due to high growth rates and low MZP grazing, are largely unaffected by mixed layer depth.

\section{Regulation of bacteria}

HNF grazing on bacteria was evident as bacterial abundance in the grazer-free fraction exceeded the other treatments after $\sim 5 \mathrm{~d}$ in Expts II and III. However, grazing estimates and regression analysis showed that grazing control of bacteria was not as strong as for picophytoplankton. This is likely due to the fact that bacteria, unlike picophytoplankton, were bottom-up controlled, e.g. that the highest growth rates were initially not obtained in the grazerreduced Treat $<0.8$ (Table 3). This suggests that BDOC produced when larger grazers and phytoplankton are present can be more important for bacterial growth than reduced grazing pressure. This may also be the case during the end of Expt II, where growth of bacteria with a high HNA:LNA ratio (Fig. 5B) was stimulated despite high grazer abundance, possibly as a consequence of the high abundance of large phytoplankton (Expt II had more than twice the chl a than in Expt III) and the subsequent excretion of BDOC. In general, we found that HNF selected for large HNA bacteria, as the HNA:LNA ratio was highest in Treat $<0.8$. This has been previously documented in fractionation and dilution experiments (Šimek \& Chrzanowski 1992, del Giorgio et al. 1996, Calvo-Díaz \& Morán 2006, Pree et al. 2016). The selection for larger bacteria also supports the HNF preference for picophytoplankton, as these are equal to the size of large bacteria (1.7 $\mu \mathrm{m}$ diameter).
Viruses may also have regulated bacteria and phytoplankton abundance. As described by Paulsen et al. (2015), the in situ V:B ratio decreased during the winter-spring transition from $\sim 10$ to 4 due to an increase in bacterial abundance, whereas the virus numbers remained unchanged. Similarly, the initial $\mathrm{V}$ :B ratio was higher in the first experimental period and subsequently declined (Fig. 5D-F). The average $\mathrm{V}: \mathrm{B}$ ratio in marine surface waters of the North Atlantic is $\sim 10$, but can reach as high as 40 to 50 (Parada et al. 2007, Suttle 2007). Thus, the encounter rate (i.e. chance of viral infection) was relatively low in our incubations, and we assume that the viral topdown regulation in the present study of the earlyspring microbial community was minimal.

\section{Grazing by MZP in early spring}

The biomass of MZP in the Iceland Basin ranged from 0.5 to $1.0 \mathrm{mg} \mathrm{C} \mathrm{m}^{-3}$, which was low compared with the average of $8.1 \mathrm{mg} \mathrm{C} \mathrm{m} \mathrm{m}^{-3}$ in oligotrophic waters (Sherr \& Sherr 2007). With the method applied here, it is impossible to make a clear distinction between the prey preferences of heterotrophic dinoflagellates and ciliates. However, we did see an increase in dinoflagellates when diatoms were abundant in Expt II, consistent with the view that dinoflagellates prefer prey equal to or even larger than their body size (Jakobsen \& Hansen 1997, Sherr \& Sherr 2007, Jeong et al. 2011), and that dinoflagellates are generally more abundant during the diatom spring bloom period (Verity et al. 1993, Sherr \& Sherr 2007). However, we found that ciliates generally dominated the MZP biomass in the Iceland Basin during the pre-bloom, which would be expected given the high abundance of small-sized prey during the study period (Bernard \& Rassoulzadegan 1990).

In comparison to studies conducted during summer in the same region (Verity et al. 1993, Gifford et al. 1995), the grazing coefficients of chl a were an order of magnitude lower. Even though MZP was released from mesozooplankton grazers in Treat $<50$, they were not able to control the growth of large phytoplankton $(>10 \mu \mathrm{m})$. However, it was observed that MZP had a grazing impact on the HNF community and that HNF were the major carbon source for MZP during Expts I and II. The consumption of HNF by MZP was proposed by Azam et al. (1983) as an important pathway, i.e. the microbial loop, but it is rarely considered, especially in dilution experiments. One reason for the MZP ability to respond to the growth in HNF and not that of the large phytoplank- 
ton may be a remnant of winter conditions, where the microbial loop pathway via HNF has been feeding the MZP community. It was evident that the MZP community increased in size at the Iceland Basin from late March to early May, supporting an ongoing general adjustment of the MZP community during the winter-spring transition. During the winter/prebloom conditions, the fast-growing picophytoplankton and HNF represented important carbon sources for sustaining MZP and transferring substantial energy up the food web, despite the low phytoplankton biomass.

\section{Microbial cascading effects}

The conceptual model in Fig. 8 illustrates the key trophic interactions observed in this study to be important in controlling the autotroph-heterotroph balance in the photic zone (modified from Thingstad et al. 2008). Picophytoplankton are usually not included in such frameworks, but based on our findings, we suggest how they can be incorporated (see bold text in Fig. 8). Originally, Thingstad et al. (2008) discussed that when the numerical response to increased food supply is fast in MZP (mainly ciliates), but slow in copepods, it will tend to prolong diatom blooms, as strong ciliate grazing restrains the smaller phytoplankton from using up the mineral nutrients. We propose a similar situation during the winterspring transition, only we find HNF to be the most important grazer, showing the most rapid response to early production and applying a strong top-down control on picophytoplankton (Fig. 8). Meanwhile, the numeric response of MZP was slower (after 6-8 d) and the MZP grazing on larger phytoplankton was

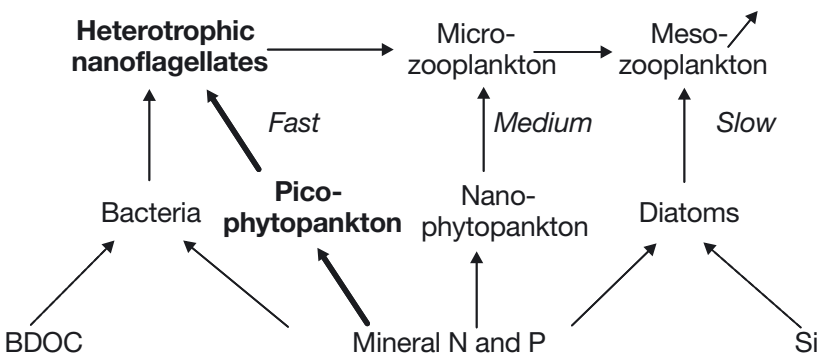

Fig. 8. Idealized microbial food web used to illustrate energy flow and interactions believed to be important in controlling autotroph-heterotroph balance in the photic zone in highlatitude systems. Modified from Thingstad et al. (2008) by adding link between picophytoplankton and heterotrophic nanoflagellates (in bold). Response time of nano-, microand mesozooplankton are here considered to be fast, medium and slow (and dependent on diapause period), respectively. $\mathrm{BDOC}=$ bioavailable dissolved organic carbon hardly measurable, and this fraction was allowed to grow (confirmed by Morison \& Menden-Deuer 2015). Our results suggest that the HNF grazers can constrain the development of picophytoplankton biomass during the pre-bloom succession, which leaves the subsequent spring bloom and nutrient depletion to larger phytoplankton, resistant to small grazers.

Acknowledgements. The research leading to these results received funding from the European Union Seventh Framework Programme project EURO-BASIN (ENV.2010.2.2.1-1) under grant agreement no. 264933, ERC grant Microbial Network Organisation (MINOS 250254) and from the US National Science Foundation (OCE-0752972). M.L.P. was supported by the project MicroPolar (RCN 225956) funded by the Norwegian Research Council. Thank you to Mario Esposito for kindly measuring nutrients during the cruise and to Aud Larsen for flow cytometry assistance. We also thank the crew on board the RV 'Meteor' and especially thank you to Françoise Morison and Chris Daniels for great teamwork and for language corrections. We are very grateful to Thomas Kiørboe and Bernadette Pree for constructive discussions and to the reviewers who helped to improve this manuscript substantially.

\section{LITERATURE CITED}

Azam F, Fenchel T, Field JG, Gray JS, Meyer-Reil LA, Thingstad F (1983) The ecological role of water-column microbes in the sea. Mar Ecol Prog Ser 10:257-263

Backhaus JE, Hegseth EN, Wehde H, Irigoien X, Hatten $\mathrm{K}$, Logemann K (2003) Convection and primary production in winter. Mar Ecol Prog Ser 251:1-14

Behrenfeld MJ (2010) Abandoning Sverdrup's Critical Depth Hypothesis on phytoplankton blooms. Ecology 91: 977-989

* Behrenfeld MJ, Boss ES (2014) Resurrecting the ecological underpinnings of ocean plankton blooms. Annu Rev Mar Sci 6:167-194

* Bernard C, Rassoulzadegan F (1990) Bacteria or microflagellates as a major food source for marine ciliates: possible implications for the microzooplankton. Mar Ecol Prog Ser 64:147-155

Bjørnsen PK, Riemann B, Horsted SJ, Nielsen TG, Pock-Sten J (1988) Trophic interactions between heterotrophic nanoflagellates and bacterioplankton in manipulated seawater enclosures. Limnol Oceanogr 33:409-420

Børsheim K, Bratbak G (1987) Cell volume to cell carbon conversion factors for a bacterivorous Monas sp. enriched from seawater. Mar Ecol Prog Ser 36:171-175

Boyd P, Newton P (1995) Evidence of the potential influence of planktonic community structure on the interannual variability of particulate organic carbon flux. Deep-Sea Res I 42:619-639

Calvo-Díaz A, Morán X (2006) Seasonal dynamics of picoplankton in shelf waters of the southern Bay of Biscay. Aquat Microb Ecol 42:159-174

Christaki U, Giannakourou A, van Wambeke F, Grégori G (2001) Nanoflagellate predation on auto- and heterotrophic picoplankton in the oligotrophic Mediterranean Sea. J Plankton Res 23:1297-1310

Christaki U, Vázquez-Domínguez E, Courties C, Lebaron P 
(2005) Grazing impact of different heterotrophic nanoflagellates on eukaryotic (Ostreococcus tauri) and prokaryotic picoautotrophs (Prochlorococcus and Synechococcus). Environ Microbiol 7:1200-1210

Cushing DH (1959) On the nature of production in the sea. Fish Invest Lond Ser II 22:1-40

* Dale T (1999) Seasonal development of phytoplankton at a high latitude oceanic site. Sarsia 84:419-435

* Daniels CJ, Poulton AJ, Esposito M, Paulsen ML, Bellerby R, St John M, Martin AP (2015) Phytoplankton dynamics in contrasting early stage North Atlantic spring blooms: composition, succession, and potential drivers. Biogeosciences 12:2395-2409

* de Boyer Montégut C, Madec G, Fischer AS, Lazar A, Iudicone D (2004) Mixed layer depth over the global ocean: an examination of profile data and a profile-based climatology. J Geophys Res 109:C12003

* del Giorgio P, Gasol JM, Vaqué D, Mura P, Agustí S, Duarte CM (1996) Bacterioplankton community structure: protists control net production and the proportion of active bacteria in a coastal marine community. Limnol Oceanogr 41:1169-1179

* Ducklow H, Kirchman D, Quinby H, Carlson C, Dam H (1993) Stock and dynamics of bacterioplankton carbon during the spring bloom in the eastern North Atlantic Ocean. Deep-Sea Res II 40:245-263

Fenchel T (1982) Ecology of heterotrophic microflagellates. IV. Quantitative occurrence and importance as bacterial consumers. Mar Ecol Prog Ser 9:35-42

Friedland KD, Record NR, Asch RG, Kristiansen T and others (2016) Seasonal phytoplankton blooms in the North Atlantic linked to the overwintering strategies of copepods. Elem Sci Anthropocene 4:000099

Fuhrman JA (1999) Marine viruses and their biogeochemical and ecological effects. Nature 399:541-548

* Garside C, Garside JC (1993) The 'f-ratio' on $20^{\circ} \mathrm{W}$ during the North Atlantic Bloom Experiment. Deep-Sea Res II 40:75-90

KGifford DJ, Fessenden LM, Garrahan PR, Martin E (1995) Grazing by microzooplankton and mesozooplankton in the high-latitude North Atlantic Ocean: spring versus summer dynamics. J Geophys Res 100:6665-6675

* Gislason A, Astthorsson OS, Petursdottir H, Gudfinnsson H, Bodvarsdottir AR (2000) Life cycle of Calanus finmarchicus south of Iceland in relation to hydrography and chlorophyll a. ICES J Mar Sci 57:1619-1627

Hansell DA (2013) Recalcitrant dissolved organic carbon fractions. Annu Rev Mar Sci 5:421-445

KHansen PJ, Bjørnsen PK, Hansen BW (1997) Zooplankton grazing and growth: scaling within the $2-2,000-\mu \mathrm{m}$ body size range. Limnol Oceanogr 42:687-704

* Huete-Stauffer TM, Morán XAG (2012) Dynamics of heterotrophic bacteria in temperate coastal waters: similar net growth but different controls in low and high nucleic acid cells. Aquat Microb Ecol 67:211-223

* Huisman J, van Oostveen P, Weissing F (1999) Critical depth and critical turbulence: two different mechanisms for the development of phytoplankton blooms. Limnol Oceanogr 44:1781-1787

₹ Jakobsen HH, Hansen PJ (1997) Prey size selection, grazing and growth response of the small heterotrophic dinoflagellate Gymnodinium sp. and the ciliate Balanion comatum-a comparative study. Mar Ecol Prog Ser 158:75-86

Jeong HJ, Lee KH, Yoo YD, Kang NS, Lee K (2011) Feed- ing by the newly described, nematocyst-bearing heterotrophic dinoflagellate Gyrodiniellum shiwhaense. J Eukaryot Microbiol 58:511-524

* Jürgens K, Gasol JM, Vaqué D (2000) Bacteria-flagellate coupling in microcosm experiments in the Central Atlantic Ocean. J Exp Mar Biol Ecol 245:127-147

*Landry MR, Hassett RP (1982) Estimating the grazing impact of marine micro-zooplankton. Mar Biol 67: 283-288

Lee S, Fuhrman JA (1987) Relationships between biovolume and biomass of naturally derived marine bacterioplankton. Appl Environ Microbiol 53:1298-1303

Li WKW, Dickie PM, Harrison WG, Irwin BD (1993) Biomass and production of bacteria and phytoplankton during the spring bloom in the western North Atlantic Ocean. DeepSea Res II 40:307-327

* Lindemann C, St. John M (2014) A seasonal diary of phytoplankton in the North Atlantic. Front Mar Sci 1:37

Marie D, Brussaard CPD, Thyrhaug R, Bratbak G, Vaulot D (1999) Enumeration of marine viruses in culture and natural samples by flow cytometry. Appl Environ Microbiol 65:45-52

Morison F, Menden-Deuer S (2015) Early spring phytoplankton dynamics in the subpolar North Atlantic: the influence of protistan herbivory. Limnol Oceanogr 60: 1298-1313

Nielsen TG, Sabatini M (1996) Role of cyclopoid copepods Oithona spp. in North Sea plankton communities. Mar Ecol Prog Ser 139:79-93

* Parada V, Sintes E, van Aken HM, Weinbauer MG, Herndl GJ (2007) Viral abundance, decay, and diversity in the meso- and bathypelagic waters of the North Atlantic. Appl Environ Microbiol 73:4429-4438

* Paulsen ML, Riisgaard K, Thingstad TF, St. John M, Nielsen TG (2015) Winter-spring transition in the subarctic Atlantic: microbial response to deep mixing and prebloom production. Aquat Microb Ecol 76:49-69

* Pree B, Kuhlisch C, Pohnert G, Sazhin AF and others (2016) A simple adjustment to test reliability of bacterivory rates derived from the dilution method. Limnol Oceanogr Methods 14:114-123

Kandaa RA, Larsen A (2006) Seasonal variations in virushost populations in Norwegian coastal waters: focusing on the cyanophage community infecting marine Synechococcus spp. Appl Environ Microbiol 72:4610-4618

* Sato M, Yoshikawa T, Takeda S, Furuya K (2007) Application of the size-fractionation method to simultaneous estimation of clearance rates by heterotrophic flagellates and ciliates of pico- and nanophytoplankton. J Exp Mar Biol Ecol 349:334-343

Sherr EB, Sherr BF (2007) Heterotrophic dinoflagellates: a significant component of microzooplankton biomass and major grazers of diatoms in the sea. Mar Ecol Prog Ser 352:187-197

* Siegel DA, Doney SC, Yoder JA (2002) The North Atlantic spring phytoplankton bloom and Sverdrup's critical depth hypothesis. Science 296:730-733

* Šimek K, Chrzanowski TH (1992) Direct and indirect evidence of size-selective grazing on pelagic bacteria by fresh-water nanoflagellates. Appl Environ Microbiol 58: 3715-3720

Suttle CA (2007) Marine viruses-major players in the global ecosystem. Nat Rev Microbiol 5:801-812

* Sverdrup HU (1953) On conditions for the vernal blooming of phytoplankton. J Cons Int Explor Mer 18:287-295 
Taylor JR, Ferrari R (2011) Shutdown of turbulent convection as a new criterion for the onset of spring phytoplankton blooms. Limnol Oceanogr 56:2293-2307

Thingstad TF, Bellerby RGJ, Bratbak G, Børsheim KY and others (2008) Counterintuitive carbon-to-nutrient coupling in an Arctic pelagic ecosystem. Nature 455: 387-390

Townsend DW, Cammen LM, Holligan PM, Campbell DE, Pettigrew NR (1994) Causes and consequences of variability in the timing of spring phytoplankton blooms. Deep-Sea Res I 41:747-765

Vaqué D, Guadayol Ò, Peters F, Felipe J and others (2008) Seasonal changes in planktonic bacterivory rates under

Editorial responsibility: Klaus Jürgens,

Rostock, Germany the ice-covered coastal Arctic Ocean. Limnol Oceanogr $53: 2427-2438$

* Verity PG, Stoecker DK, Sieracki ME, Nelson JR (1993) Grazing, growth and mortality of microzooplankton during the 1989 North Atlantic spring bloom at $47^{\circ} \mathrm{N}, 18^{\circ} \mathrm{W}$. Deep-Sea Res I 40:1793-1814

*Verity PG, Wassmann P, Frischer ME, Howard-Jones MH, Allen AE (2002) Grazing of phytoplankton by microzooplankton in the Barents Sea during early summer. J Mar Syst 38:109-123

Zubkov MV, Burkill PH, Topping JN (2006) Flow cytometric enumeration of DNA-stained oceanic planktonic protists. J Plankton Res 29:79-86

Submitted: April 14, 2016; Accepted: November 14, 2016

Proofs received from author(s): February 2, 2017 